Article

\title{
Social and Political Attitudes of Moscow Students on the Background of the All-Russia and Regional Youth Studies
}

\author{
Tatiana Litvinova ${ }^{1, * \mathbb{C}}$, Olga Vershinina ${ }^{2}$ and Gennady Moskvitin ${ }^{3}$ \\ 1 Department of Regional Governance and National Politics, Moscow State Institute of International Relations, \\ Moscow 119454, Russia \\ 2 Department of Finance and Banking, Russian New University, Moscow 105005, Russia; oliga.06@mail.ru \\ 3 Department of Production Management and Staffing of the Transport Complex, Russian University of \\ Transport, Moscow 127994, Russia; mgi81@mail.ru \\ * Correspondence: tantin@mail.ru
}

Received: 15 July 2020; Accepted: 2 September 2020; Published: 4 September 2020

check for updates

\begin{abstract}
The purpose of the article is to study the socio-political attitudes of Moscow students, which determine their life strategies in the public sphere. An empirical basis for the study was the sociological survey of students of three universities in Moscow $(n=768)$. The questionnaire was partially based on Milton Rokeach's terminal personal values indicators and the methodology of studying political culture of Gabriel Almond and Sidney Verba, adapted to a Russian context. The survey data operationalization let us represent a structural model of socio-political attitudes of Moscow students, which consists of indicators of four levels: value, emotional, cognitive, and strategic. The results showed that students in Moscow share the values and patriotic feelings of the elder generations. The influence of gender and age factors was most pronounced on the level of personal values. Despite of the field of their study, students in Moscow can be described as quite energetic and optimistic young citizens, equally family and career oriented with not a high interest in politics and weak political activity. Authors discussed their main findings with the results of previously obtained all-Russian and regional youth studies.
\end{abstract}

Keywords: social values; political attitudes; Moscow students; all-Russia youth studies; regional surveys

\section{Introduction}

During the transition to adulthood, young people face various social and economic challenges, which affect their participation in social and political processes. It largely depends on their values and social attitudes. Young people are the most active part of the population, the future of the state is in their hands, which makes youth studies an important and relevant research direction.

Social and political attitudes of young people occupy a special place in youth studies. Moreover, they can be viewed from different approaches. First, psychologists offer a cognitive view of values, their acquisition, and development from adolescence to adulthood (Piaget 1972). Developing the work of Piaget, Kohlberg (Kohlberg 1984) traced the moral development of a person far beyond the boundaries of those ages that were studied earlier, and determined that the concept of justice plays a major role in the process of moral development, and that this development occurs throughout a person's life. Currently, studies of political psychologists are focused on the direct influence of character traits (openness, conscientiousness, extraversion, agreeableness, neuroticism) on political attitudes and actions (Cawvey et al. 2017). Western authors, relying on the achievements of social psychology, 
emphasize the individualization of personal moral development, while Russian scientists (Diligenskiy 1994) consider that value orientations often proceed from the social and cultural environment.

Second, specialists in education consider that school took responsibility for teaching social and political values; they study practice and perspectives of values education and quality of teaching (Lovat et al. 2010). For instance, most of them conclude that the length of education has a liberalizing effect on social attitudes (Kaiser and Lilly 1975; Lipset 1983). Some authors consider that democratic regimes would not exist without educated people and that education has a critical importance in raising citizens in democracy (Galston 2001; García Bedolla 2010). Davies and Hogarth (2004) stated that the effectiveness of youth in public life depends on political literacy and connected it with the learning of political subjects at schools. German scholars (Fischer et al. 2017) made an interesting conclusion; they found the link between forming liberal promarket views and studying economics.

Third, the political scientists study youth civil identity, political values, and participation culture (Plutzer 2002; Alford et al. 2005). According to Welzel and Inglehart (2010, p. 47), youth is seen as an agent of social change and "cultural evolution" and has an evolutionary view of social values, since they are "less of a lifetime invested into old values and role models, they can more easily detach their identity from traditional patterns". Youth are inherent in such guidelines and behavior patterns as secular rationality, openness, and tolerance. Youth studies are gaining great importance across the world, precisely because its values and attitudes will determine the future of social development.

The Fundamentals of the State Youth Policy of the Russian Federation until 2025, approved by the Government on 29 November 2014, categorize "youth" as people "at the age of 14 to 30 years, and in some cases determined by regulatory legal acts of the Russian Federation and subjects of the Russian Federation-up to 35 years or more" (Order of the Government of the Russian Federation 2014). Based on the Federal State Statistic Service (2020), 36.1 million people in Russia are in the age group from 15 to 34 years, which is $24.6 \%$ of the country's population. The age structure of the Russian population is shifting towards aging, and declining the share of youth. The decline in the number of young people due to demographic processes is not uniform across the subjects of the Russian Federation. The republics of the North Caucasus, which are currently leaders in terms of the proportion of youth, Dagestan, Ingushetia, and the Chechen Republic have more than 30\% of young people in the population. In the Siberian Federal District, the Tomsk region stands out with the share of youth of more than $28 \%$, while in other regions of Siberia and the Far East the share of youth in the population is less than the average for Russia. It can be explained by the fact that Tomsk is one of the largest centers of higher education. However, in Moscow, the largest university center in the country, the proportion of young people is less than $20 \%$. The share of young people in the population of Saint Petersburg is $22 \%$.

The modern youth of Russia is extremely differentiated in terms of its share in the population in different regions, in access to education and cultural benefits, in terms of the values and possibilities for realizing their aspirations. Obviously, living in the center of Russia, in cities such as Moscow or Saint Petersburg, or at least in millionaire cities such as Nizhny Novgorod, Novosibirsk, Yekaterinburg, and Kazan, can give young people much more opportunities for self-realization. Based on the Federal State Statistic Service (2020), the share of young people aged 15-25 in Russia who do not study, do not work, and do not acquire professional skills in 2018 was $10.2 \%$. Among urban youth-10\%, among rural youth $-18 \%$, among men-10.7\%, among women-14\%. The share of the population of Russia aged 25-34 with higher education is quite high-40.3\%.

Thus, the important practical questions for youth studies in modern Russia are: Does the place of residence affect the social and political activity of Russian youth? What are the career and family attitudes of Russian youth, and do they depend on gender? Do the political values of young people depend on the field of their study?

Long-term studies of the values, social orientations, and civic consciousness of young people in Russia are carried out by the Institute of Sociology of the Russian Academy of Sciences (Gorshkov and Sheregi 2010,2019). Along with the generalized value look of youth, they analyzed the value profile of 
university students as the future intellectual elite of the state. The preferences of modern students characterize eleven basic values in a hierarchical order: family, health, education, friends, freedom, work, career, money, homeland, faith, power (Gorshkov and Sheregi 2019, p. 155). Public life and social values of youth from the peripheral parts of Russia are also in the focus of scholars. The regional aspects of socio-political attitudes of Russian youth based on sociological surveys have become quite popular during the last years. Thus, patriotic consciousness of the Siberia regions youth (Altaisky krai, Krasnoyarsky krai, Omskaya oblast, and Republic of Altai) was studied by Omelchenko et al. (2015). Shevchenko and Vagina (2017) paid special attention to the civic patriotism as an idea for youth consolidation in the South of Russia. Simonyan (2018) made the comparative analysis of the worldview, beliefs, and attitudes of youth of the Western (Kaliningrad, Saint Petersburg, Petrozavodsk) and Eastern (Vladivostok, Khabarovsk, Blagoveshchensk) border regions of Russia. Moscow students have also become the object of special attention (Sazonova 2014; Litvinova 2018).

In Moscow, according to the Mosstat (2020), 706.1 thousand students were enrolled in higher educational institutions by the end of 2018 , which is $5.6 \%$ of the permanent population of the capital. Moscow students are those who are likely to join the ranks of the middle class and the political, economic, and cultural elite of the country.

The purpose of the article is to study the socio-political attitudes of Moscow students, which determine their life strategies in the public sphere.

\section{Methodology}

The problem of definition and indicators of attitudes is one of the classic problems for sociology. In the well-known definition of Allport (1935, p. 810), attitudes were interpreted as cognitive representations in the mind of the individual, which express his "mental and neural states of readiness" for a certain way of directed activity. Later, social attitudes began to be understood as specific products of collective consciousness and culture, adopted by individuals. Rokeach (1968) considered them already in a purely cognitive way, as a relatively stable system of ideas of the subject about a social object or situation in time, which predisposes him to the choice of a certain behavior. In this sense, social attitudes are often regarded as similar to social values. Rokeach $(1973$, p. 27$)$ divided social values into two main categories: 18 terminal values or values-goals, expressing the idea of a person about what to strive for in life (family security, friendship, self-respect, happiness, freedom, pleasure, etc.), and 18 instrumental values or values-means (ambition, self-control, courage, politeness, honesty, etc.), which focus on the main ways to achieve these goals.

The methodological breakthrough in the study of social attitudes was made in 1981, with the beginning of the large-scale empirical World Values Survey that covered more than 80 countries. In the research initiated by Inglehart (1990), the typology of "materialistic-post-materialistic values" was applied, which was based on the well-known hierarchy of needs of Abraham Maslow. By "materialistic values", Inglehart meant the orientation of the respondents towards material well-being, economic growth, the fight against crime, etc., by "post-materialistic" — the orientation towards prestige, self-realization, mutual understanding, etc. On the basis of empirical results, Inglehart came to the conclusion that there are two hierarchies of value concepts in the value consciousness of the Western European population: "materialistic" and "post-materialistic". At the same time, the first group of values is more essential for older generations, and the second is more important for the younger generation. The studies demonstrate changes in people's values in adaptation to living conditions in comparative perspective (Welzel and Inglehart 2010). Sociologists interviewed all segments of the population using standardized questionnaires that measured changes in values related to religion, gender relations, work motivation, democracy, governance, social capital, political participation, tolerance, environmental protection, and subjective feelings of well-being.

Verba and Almond (1963) surveyed civic culture in Germany, Italy, Mexico, Great Britain, and the US and became the classics of the study of political attitudes. They proposed three forms of political orientation: (1) cognitive level (thoughts)—the citizens' interest in social and political 
events, the problem of political participation, the level of trust in the political system; (2) affective level (feelings)_possible reactions of people to violations of their rights; (3) value level, "the judgments and opinions about political objects that typically involve the combinations of value standards and criteria with information and feelings" (Verba and Almond 1963, p. 14).

Our research was partially based on Milton Rokeach's terminal personal values indicators and the methodology of studying political culture of Gabriel Almond and Sidney Verba, adapted to a Russian context. In the survey, we paid special attention to trust in state and public institutions. Trust in institutions is the result of people's interactions with institutions, including emotional and rational components, individual and collective experiences (Mishler and Rose 2007). This approach is especially important for understanding the specifics of trusting the authorities among Russian youth. Socio-economic factors underlie this characteristic and determine the level of optimism and opportunities for self-realization in a specific socio-political environment (Feldman and Johnston 2014). The position of youth in the socio-political structure of society is an objective factor of youth optimism, which must be taken into account when studying political attitudes.

\section{Materials and Methods}

\subsection{Survey Questionnaire}

The key part of the empirical base of this work is the materials of a mass sociological survey (questionnaire) of Moscow students consisted of two set of questions defining social and political attitudes of youth. All questions were closed-ended, each with an indication of the possibility for the respondents to choose single or multiple (up to 3) answer options.

The set of social questions was oriented to highlight the basic values and life aspirations of Russian youth: family, comfortable life, freedom, social recognition, love, friendship, career, etc. Several questions were aimed at clarification of life orientations and future plans of young people (the ideas of the most promising areas of employment, career expectations, and attitudes towards starting a family). For these questions, we used nominal scales, with the help of which it is possible to fix the respondent's opinion about something, his/her attitude, and motive.

For the set of questions devoted to political orientations in formulating the proposed answer options, we partially used the tools and options tested by other researchers of the youth political orientations in Russia (Gorshkov and Sheregi 2019; Petukhov 2012; Shevchenko and Vagina 2017; Simonyan 2018; Stegny 2016). This part of survey was aimed at identifying three levels of attitudes of young people:

(1) cognitive level:

- $\quad$ the students' interest in social and political events (four-point ordinal scale from full attention to lack of interest);

- the level of trust in the political system (nominal scale-list of public institutions, respondents were asked to choose up to 3 deserved the greatest trust);

(2) emotional level:

- possible reactions of students to violations of their rights (nominal scale, closed-ended list of possible reactions-single choice);

(3) values level:

- young people's ideas about the best socio-economic system (nominal scale-list of socio-economic principles);

- $\quad$ the correlation of their life plans with the social development (a nominal scale designed to determine the degree of the respondent's dependence on objective conditions, his/her own efforts, or on the social conditions in the country and his/her own actions equally). 
One of the most striking characteristics of a generation is the level of satisfaction with living conditions-the respondent's confidence that he/she can realize personal plans for the future (a five-point ordinal scale from complete confidence to no confidence).

At the end of the questionnaire there was a block of questions to collect demographic data (gender, age) and field of study, but they were not specific enough to identify students.

\subsection{Sample and Data Collection}

The survey was conducted in February-March 2020. The research sample $(n=768)$ consisted of Bachelor and Master students of full-time education in the humanities, economics, management, and engineering education in three universities: Moscow State Institute of International Relations (MGIMO), the Russian New University (RosNOU), and the Russian University of Transport (MIIT). Sample type: directional (targeted). The sampling method was combined; it included the method of "available cases" and the method of "typical representatives". First, spatial localization was carried out - the selection of Moscow universities, then the possibility of "access" to specific higher educational institutions was determined, after that student groups (clusters) were selected, which were further questioned in a continuous manner. In connection with the current epidemiological situation, it was decided to conduct an absentee survey using online tools (Webanketa.com). The link was sent to respondents with given socio-demographic characteristics. The processing of the results included methods of frequency analysis and contingency of features. The main research questions were analyzed through the prism of independent variables, to which we attributed gender, age, and field of study. We interviewed 768 students, which corresponds to the required size of a representative sample for the general population of Moscow students $(\mathrm{N}=706.1$ thousand people) with a confidence level of $95 \%$ and margin of error of $\pm 3.5 \%$. The age of respondents was from 18 to 30 years. Among the respondents there were 376 (49\%) young men, and 392 (51\%) girls. Survey data provide an opportunity to empirically investigate the socio-political attitudes of youth studying in Moscow.

The main characteristics of the survey sample are summarized in the following table (Table 1):

Table 1. Survey respondents' main characteristics.

\begin{tabular}{ccccccccccc}
\hline \multicolumn{4}{c}{ Gender } & \multicolumn{2}{c}{ Age } & \multicolumn{3}{c}{ University } & & Field of Study \\
\hline & M & F & $18-24$ & $25-30$ & MGIMO & RosNOU & MIIT & Humanities & $\begin{array}{c}\text { Economics and } \\
\text { management }\end{array}$ Engineering \\
Number & 376 & 392 & 523 & 245 & 179 & 244 & 345 & 205 & 324 & 239 \\
\hline
\end{tabular}

We also got acquainted with the results of sociological studies carried out by VCIOM (Russian Public Opinion Research Center) on related issues, such as career aspirations and social well-being of young people, in order to clarify the social context. Since in the formulation of questions for the survey, we partly used the tools previously tested in all-Russian and regional youth studies, we discussed the data obtained with the results of other authors.

\section{Findings}

\subsection{Social Attitudes of Moscow Students}

According to the results of the survey, the most perspective fields of employment for youth from the students' point of view are: technologies, trade, and public administration. Surprisingly, students studying humanities consider technologies more promising than their sphere of interest. Law, communication, banking, finance, insurance, transport, and logistics also seem very promising. It was unexpected to see that science and education gained almost $19 \%$ of votes. Catering and consumer services are not popular among students of all fields of study (Table 2). The discrepancies in the answers of young men and women are not statistically significant. 
Table 2. What areas do you think are the most promising for young people's employment? (Multiple choice-up to 3.).

\begin{tabular}{cc}
\hline Answers & \% of Respondents \\
\hline Newest technologies & 49.7 \\
Trade & 30.7 \\
Public administration & 29.6 \\
Law & 29.0 \\
Communications, PR & 28.5 \\
Banking, finance, insurance & 24.0 \\
Transport, logistics & 18.9 \\
Science and education & 18.9 \\
Security, military service & 18.4 \\
Physical culture and sports & 16.2 \\
Industry & 15.6 \\
Health care & 12.8 \\
Construction, repair & 11.7 \\
Culture and arts & 8.9 \\
Agriculture & 7.2 \\
Catering & 5.6 \\
Consumer services & 2.8 \\
\hline
\end{tabular}

When defining a "successful career" (single choice), about half of respondents (49\%) decided that it meant "moral satisfaction from work, the opportunity to do what you love"; $26 \%$ chose as criteria "high income", 10\% chose "achieving a high level of professional skill"; $5 \%$ decided that a successful career depended on a high position, and only $4 \%$ of respondents said it meant "opportunity to benefit society". Employment in a field of specialty is not an important guideline, as well as universal recognition or prestige of a profession (organization). In the hierarchy of preferences, the top answer "moral satisfaction" did not show any gender differences, but the "high income" turned up more significant for young women $(27 \%)$ than men $(23 \%)$. Furthermore, $12 \%$ of girls chose "achieving a high level of professional skill", compared to $7 \%$ of young men. The answers "high position" and "prestige of the profession, organization" chosen by $6 \%$ and $3 \%$ of men respectively, were totally ignored by women. This can be explained by the fact that Russian women become more career oriented, and their motives to earn more and be perfectly skilled tend to grow, while the position and prestige are traditionally more important for men. The field of study did not show any significant influence on choices. Thus, we saw that material reward is not a dominant motivation for making a career among Moscow students.

We also asked the respondents: "What factors primarily affect the career of young people"? Despite the fact that multiple choice put on the top the meritocratic characteristics of personal qualities and merits $(65 \%)$ and good education (57\%), the availability of right and profitable contacts and acquaintances took third place $(44 \%)$. Students also noted the importance of foreign languages, professional experience, and computer literacy for a good career.

The results of answering the question "What values are the most important in a person's life?" are represented in Table 3. The majority of students indicated family happiness as the highest value. The health was at the second place; the wealth was on the third. Personal freedom and independence gained almost $34 \%$ of votes. About a quarter of respondents preferred to have faithful friends. The career as the desired value gave place to true love. Opportunities to realize their talents and get interesting job gathered the comparable shares of respondents. About $7 \%$ of students would like to benefit other people, a bit smaller share preferred a quiet life. The desire for glory and power were placed at the end of the values' list according to the answers. 
Table 3. What values are the most important in a person's life? (Multiple choice-up to 3.)

\begin{tabular}{cc}
\hline Answers & \% of Respondents \\
\hline family happiness & 59.2 \\
health & 48.0 \\
wealth & 40.8 \\
personal freedom and independence & 33.5 \\
faithful friends & 25.1 \\
true love & 18.9 \\
career & 18.4 \\
interesting job & 17.9 \\
the opportunity to realize your talents & 17.32 \\
opportunity to benefit other people & 7.3 \\
quiet life & 6.7 \\
fame, universal recognition & 3.9 \\
power, the ability to lead other people & 2.8 \\
\hline
\end{tabular}

This question showed the most influence of the gender factor on the distribution of answers. The "family happiness" was important for $70 \%$ of women compared to $49 \%$ of men; $49 \%$ of young women chose "wealth" compared to 32\% of men. The only answers where the gender factor did not turn up were "health" and "freedom" that showed their universal meaning. It is interesting that "true love" turned up more important for men (24\%) than women (14\%). All these answers showed that Moscow girls as more pragmatic individuals preferring a traditional family and a solid material base instead of romantic love. Men were expectedly more "career" oriented $(21 \%)$ than women $(16 \%)$ and looking for "faithful friends" more eagerly (36\%) than girls (15\%). The answer "power, the ability to lead other people" was ignored by girls, while $6 \%$ of men decided it to be important. We should note that "interesting job" and "opportunity to benefit other people" were more important for young women than men-to compare $22 \%$ against $14 \%$, and $11 \%$ against $3 \%$. It showed the Moscow girls not only as more altruistic but also more oriented towards professional skills growth.

Following the opinion of the majority that the main value is family happiness, it was interesting to know the marriage plans of youth. Answering the question "When do you plan to start your own family?" (single choice), $44 \%$ of students stated "after meeting the right person"; $27 \%$ of respondents answered they first need to reach material well-being; $13 \%$ declared "we'll see"; almost $11 \%$ chose "after graduation"; and about 5\% were not going to start family and getting married ever. Girls mostly connected the appropriate time for starting a family with the "meeting the right person" (54\%), more than young men $(20 \%)$, while men preferred to reach "material well-being" before marriage (compare $34 \%$ of men against $21 \%$ of women). As for those who did not plan to start a family there were $7 \%$ of young men and $3 \%$ of women.

The last question from the youth social attitudes block was devoted to the expected number of children. Surprisingly, $44 \%$ of Moscow students who participated in the survey wanted to have two children, and $22 \%$ were ready to have three and more; $18 \%$ found it difficult to answer; about $8 \%$ expected they would have one child and the same share gave the answer they preferred "child-free" life. It is interesting that "child-free" and "three and more children" orientations did not show statistically significant dependence of gender. Girls are more oriented to have two children- $47 \%$ compared to $39 \%$ of men, while young men preferred to have one child- $-11 \%$ compared to $4 \%$ of young women. The most significant observation is that all $13 \%$ of women who found it difficult to answer about desired number of children were master level students older than 22. That meant their choice to continue their studies postponed the decision to have a child. As for the $20 \%$ of men who doubted to answer, they all were younger than 24 , which might mean that older aged students had more concrete plans about desired family size. 


\subsection{Political Attitudes of Moscow Students}

First of all, we tried to find out the interest of Moscow students to domestic political and economic events. About $49 \%$ of respondents answered that they are closely watching the political events inside Russia, 42\% admitted they followed the news without special interest, $6 \%$ were not interested in political and economic events, and 3\% could not give a definite answer. The interest in the political events was $18 \%$ more essential to young men than women and $12 \%$ more expressed among master students than bachelor. Thus, the Moscow youth are not very interested in politics, but we can see gender and age dependence of this indicator.

The low interest in political events affects the political activity, which, first of all, is expressed in participation in elections. About $32 \%$ of respondents answered that they were trying to take part in elections "if time allows"; only 26\% declared they did not miss any elections, 20\% admitted that they never took part in elections, 15\% answered "rarely", and 7\% found it difficult to answer. It can be said that the number of those who declared their interest in political and economic events in the country roughly coincided with those who participated in elections (always or if they had time). However, it remains that more than $40 \%$ of students ignore the elections often or always. The political participation did not show statistically significant gender, age, or specialization dependence. Thus, we can observe the "contemplative" political activity of Moscow students. We suppose that low political activity is directly linked with trust in power and authority institutions. Thus, we included the question about political and social institutions that deserved trust in the students' opinion. The rating of trust is headed by the President of the Russian Federation (Table 4), followed by public organizations, business, law enforcement agencies, and the Government of the Russian Federation.

Table 4. What social and political forces in modern Russia, in your opinion, deserve the most trust? (Multiple choice-up to 3.).

\begin{tabular}{cc}
\hline Answers & \% of Respondents \\
\hline President of Russian Federation & 63.7 \\
Public organizations & 50.3 \\
Business representatives & 33.4 \\
Police, prosecutors, courts & 31.8 \\
Government of the Russian Federation & 29.6 \\
Moscow Mayor & 20.7 \\
Council of Federation of the Federal Assembly of the Russian Federation & 16.2 \\
Church, religious organizations & 15.6 \\
Mass media & 13.4 \\
State Duma of the Federal Assembly of the Russian Federation & 12.3 \\
\hline
\end{tabular}

Young men were less inclined to trust in authority institutions than girls: 58\% trust in President of Russia among men, compared to $68 \%$ among girls, but demonstrated more trust in representatives of business ( $41 \%$ of men compared to $25 \%$ of women). It is a disappointing fact that mass media and the lower chamber of the Russian parliament were the least trusted institutions in the youth's opinion, though they must serve the interests of society in the information and legislative spheres.

We asked students, "If your rights are violated, what are you ready to do?" (single choice). It is noteworthy that with a low-level trust in the law enforcement system (33\%), in case of violation of their rights $41 \%$ of respondents would complain to the police, prosecutor's office, or the court. About $16 \%$ of the surveyed students would not do anything, because they were sure that any actions would be unsuccessful. More than 13\% would apply to the authorities; the same share of respondents was going to attract public attention (apply to the media or public organizations). No less than 10\% of respondents were ready to "use personal connections and bribes" and only $6 \%$ of students answered that they could come up with protests. Thus, the positive fact is that most young people in conditions of risk and uncertainty, as a rule, act within the framework of legal procedures, and only a small percentage is able to protest. 
Most surveys on civic culture and consciousness include the question of patriotic feelings. To the question "Do you consider yourself a patriot of Russia?" (single choice), 76\% of students gave a certain positive answer, $8 \%$ said definitely "no", and 16\% found it difficult to answer. With such a dispersion of answers, it was interesting for us to find out the meaning of the concept of "patriot of Russia" in the students' opinion (Table 5).

Table 5. What, in your opinion, does the concept of "patriot of Russia" include? (Multiple choice-up to 3.).

\begin{tabular}{cc}
\hline Answers & \% of Respondents \\
\hline love to motherland & 65.4 \\
pride in the country's great achievements & 50.3 \\
performance of duties of a citizen, compliance with laws & 43.6 \\
if necessary, to protect the country with arms in hand & 37.9 \\
knowledge and pride of the country's culture & 36.3 \\
faith in the great future of the country & 29.1 \\
active struggle against internal threats & 27.9 \\
nostalgia away from homeland & 9.5 \\
\hline
\end{tabular}

The study revealed a generally positive attitude towards the concept of patriotism. At the same time, the dispersion of meanings gives an ambiguous picture, where more than $20 \%$ of respondents did not give a positive answer to the question whether they consider themselves to be patriots of Russia. Although, it should be noted that a large number of foreigners are studying in Moscow (an undefined percentage of them could participate in the survey). An important factor in the formation of patriotism is the attitude to the country's history and culture, its achievements, and faith in its future. At the same time, patriotism in the minds of students exists not only as an abstract concept, some of the respondents identified its active component_compliance with the laws and the citizenship duties, the struggle against external and internal threats of the country. An active component of patriotism demanding the protection of the country "with arms in hand" was chosen more by engineering students (56\%) than economists (36\%) and humanities (22\%).

We also investigated young people's ideas about the best socio-economic system, and took into account that the generally accepted division into liberals, communists, and socialists practically did not reflect the views of today's youth. Therefore, they were asked a question: "Which of the listed principles embody your idea of a better socio-economic system?". The answers to this question give a fairly clear presentation of the ideological orientations of the respondents, since only a single choice was possible. In the list of principles, we gave the characteristics of four socio-economic systems: (1) socialism; (2) market economy; (3) welfare state; (4) left-liberal views (Table 6).

Table 6. Which of the listed principles embody your idea of a better socio-economic system? (Single choice.).

\begin{tabular}{ccc}
\hline Answers & \% of Respondents & Number of Respondents \\
\hline $\begin{array}{c}\text { social justice, equality of opportunity, public and state control } \\
\text { over the distribution and use of national wealth } \\
\text { freedom of enterprise and private property, state }\end{array}$ & 43.0 & 330 \\
$\begin{array}{c}\text { non-interference in the economy, "who works, eats", low taxes } \\
\text { for all forms of business }\end{array}$ & 21.8 & 167 \\
$\begin{array}{c}\text { progressive tax, welfare state, emphasis of state and public } \\
\text { institutions on the development of "human capital" }\end{array}$ & 15.6 & 120 \\
$\begin{array}{c}\text { maximum personal freedom of opinion, movement, with strict } \\
\text { state control over large businesses } \\
\text { none of the above } \\
\text { Total }\end{array}$ & 10.1 & 78 \\
\hline
\end{tabular}


It should be emphasized that today's Russian youth is difficult to correlate with any clear ideological views; the distribution of answers to this question allows us only to indicate inclinations of young people. However, we can make some interesting observations. The most unexpected discovery was the preferences of socialist views on social justice and state control over the economy by more than $40 \%$ of the respondents, in contrast to the liberal ideas of free enterprise and the market, which did not collect even a quarter of the votes. The only explanation for this fact is the influence of parents and the older generation who received education and experience of socialization in the Soviet Union. The principles of a welfare state gained a bit more than $15 \%$ of respondents' votes. The libertarian views-the maximum personal freedom with the strict state control over large businesses-were supported by $10 \%$ of the respondents. Perhaps, we did not offer enough options to meet the preferences of all respondents.

One of the important characteristics that determine the generation of young people is the level of optimism. The results of the study showed that $82 \%$ of Moscow students were more or less sure that they would be able to realize their plans for the future. The objective factor of optimism among students in Moscow is their smaller involvement in everyday adult problem solving, as well as the wide opportunities that the country's capital can provide for self-realization. Practice shows that the level of optimism tends to decrease with age.

Social well-being and expectations are closely related to the perception of the situation in the country and its influence on the objective living conditions. To the question "What mostly determines your well-being in your opinion?" (single choice), $43 \%$ of respondents answered that they were equally dependent on living conditions and their own efforts, but a rather large percentage (40\%) considered that their well-being depended only on themselves, their commitment and activity. Only $13 \%$ of students answered that their well-being depended only on the social situation in the state. The distribution of answers showed that Moscow students were not inclined to lay on full responsibility for their well-being only on objective factors, there was a large percentage of those who believed that it is necessary to be active and purposeful.

Finally, to the question "What do you think hinders the life plans of young people in our country?" most of the respondents pointed the general socio-economic situation in the country, the lack of demand for youth in the labor market, and noted the absence of effective youth policy (Table 7).

Table 7. What do you think hinders the life plans of young people in our country? (Multiple choice-up to 3.).

\begin{tabular}{cc}
\hline Answers & \% of Respondents \\
\hline General socio-economic situation in the country & 55.9 \\
Lack of demand for youth in the labor market & 53.1 \\
Ignorance of where and how to apply one's strength & 49.7 \\
Lack of effective government policies to support youth & 45.3 \\
Mentality of modern youth, low activity & 35.2 \\
Discrimination of young people by older generations & 31.2 \\
Unavailability of quality education & 29.6 \\
\hline
\end{tabular}

Thus, in the opinion of young people, the responsibility for their possible failures lies primarily on the state and society, due to the lack of an effective policy to support youth, not being in demand on the labor market, and age discrimination. At the same time, more than a third of respondents recognized the low level of activity of the youth themselves. Answers to the last two questions of the survey suggest that students evaluate the influence of objective factors on their success very contradictory: misgivings of the social environment are combined with optimistic expectations. However, in general, Moscow students demonstrate an active life position. 


\subsection{Data Operationalization}

The socio-political attitudes of youth are orientations of the young generation in the public space, determined by personal values and social conditions, which express their life strategies and aspirations.

The socio-political attitudes of modern Russian youth is a complex, dynamic phenomenon that includes social guidelines for building life strategies and political guidelines that determine the issues of citizenship and behavior in the public sphere. The study allows us to present the structure of the socio-political attitudes of young people, which consists of indicators of four levels: value, emotional, cognitive, and strategic (Figure 1).

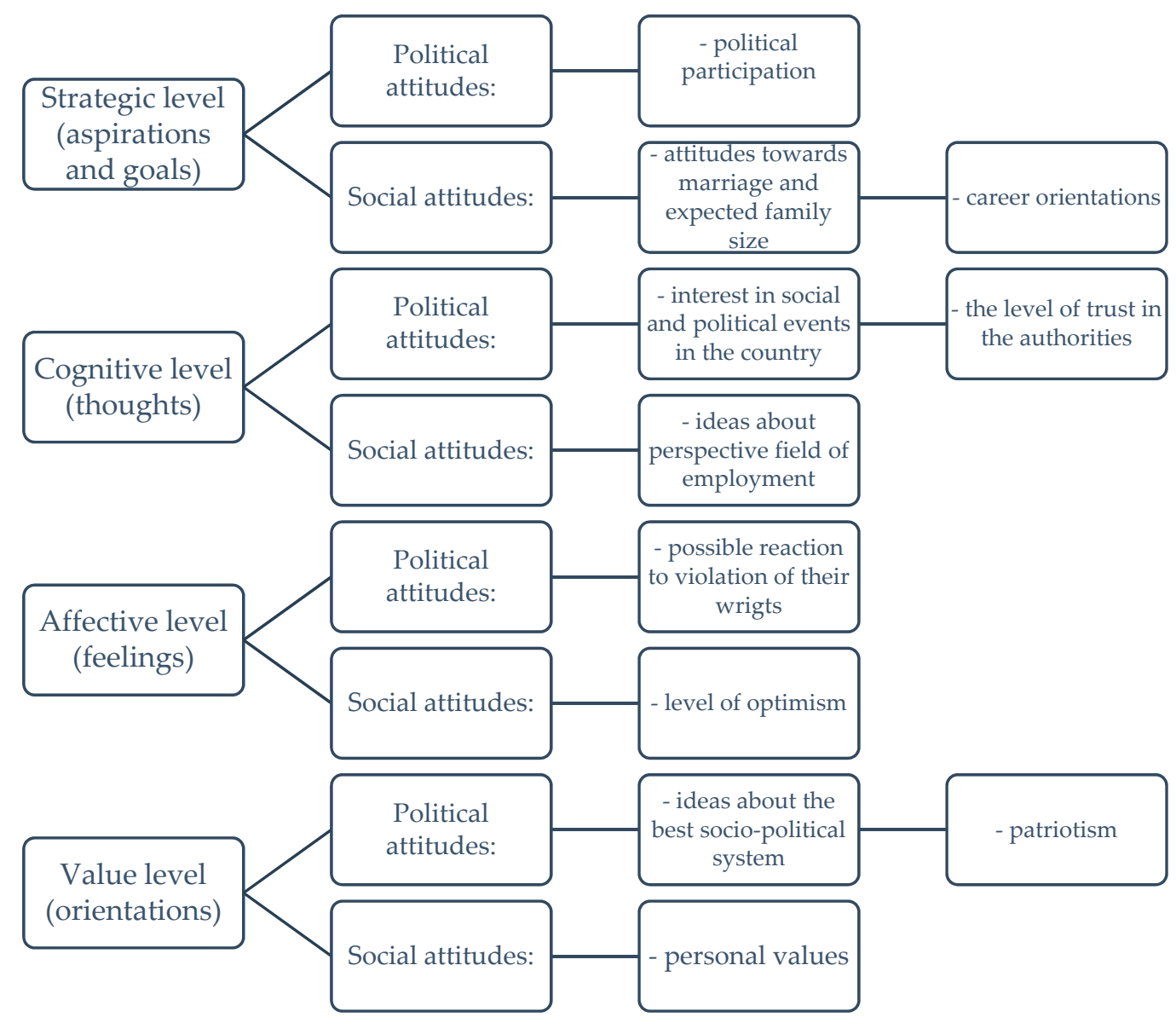

Figure 1. The structural model of socio-political attitudes of Moscow students.

Socio-political attitudes of young people at the value level are: personal values, ideas about the best socio-political structure, patriotism. The emotional level of students' socio-political attitudes includes: the level of optimism, possible reactions to violation of their rights. The cognitive level of the socio-political orientations of youth includes: ideas about promising areas of employment, interest in socio-political events in the country, the level of trust in the authorities. The strategic level represents indicators that reveal the aspirations and goals of students: the time of marriage and the desired family size, career benchmarks, political participation.

The main questions of the survey were analyzed from the standpoint of such objective variables as gender, age, place of residence (Moscow), field of study. On the part of the social macroenvironment, the main factors influencing the socio-political attitudes of young people are: the level and quality of life, the state of social infrastructure, the level of employment, the degree of social differentiation, as well as social well-being. Taking these characteristics into account allows us to study the strategies 
of the generation of young people living in the very center of socio-political and economic changes in Russia.

On the value level, we see more sympathies of Moscow youth to socialist views even among those who did not live in the Soviet Union, which can be explained by influence of elder generations. They have moderate patriotic feelings with a strong active component-understanding that being a patriot demands responsibilities. Personal values focus on traditional priorities: family, wealth, and health.

On the emotional level, most of the students prefer to act in the legal frameworks even in the case of violation of their rights. They are also quite optimistic about the realization of their future plans and lay responsibility for their future mostly on their own efforts rather than on social conditions.

On the cognitive level, the ideas of Moscow youth about perspective fields of employment are based on common views of directions of socio-economic development, so despite the field of their study they pointed out technologies, trade, and public administration. They have a moderate interest in politics and a low level of trust in public institutions.

As for operational strategies, Moscow students are both family and career oriented with contemplative political activity and low political participation.

Our findings let us to characterize Moscow students as more active in the social than the political sphere.

\section{Discussion}

Our study focuses on social and political attitudes of young people getting higher education in the capital of the Russian Federation. However, living and graduating in Moscow give the youth much more opportunities and career perspectives, especially in economic and political spheres, than in other parts of the large country. Hence, it is of critical significance to analyze and discuss our findings against the background of previously made all-Russia and regional surveys.

The hierarchy of basic social values shows the smallest discrepancies in the results of different surveys. For instance, Gorshkov and Sheregi (2019) revealed the top three values of modern youth: family, wealth, and interesting job, but popularity and power were on the bottom. Let us compare with our list of top three values: family happiness, health, and wealth, but universal recognition and power were also at the end. We agree with their main conclusion that "today's Russian youth as a whole are not individualistic, not aggressive, do not seek power, are not ambitious, they are just normal" (Gorshkov and Sheregi 2019, p. 151).

As for political values of the Russian young generation, we observe that the de-ideologization-the number of adherents of specific political attitudes, left or right-has decreased. Though we revealed the remarkable percentage of believers in the ideals of socialism and much smaller share of those who prefer the principles of liberal economic system, our findings do not contradict much the conclusion of Stegny (2016, p. 10), who conducted a survey among students of the Perm National Research Polytechnic University. About $43 \%$ of his respondents preferred the combination of the market with national specific as the ideal socio-economic system, $17 \%$ expressed sympathies to the welfare state, $5 \%$ wanted to return to the Soviet system, but the principles of the liberal market were even less preferable than in our results-only 15\%. Thus, Moscow and Perm students demonstrated the commitment to the strict state control over the economic system. We explained this with influence of the elder generation. The recognized Russian authority in the study of the personal social orientation (Diligenskiy 1994, pp. 135-39) wrote that many views are acquired by the individuals in finished form from the social experience of other people, representatives of their social group (environment). Certain values, beliefs, and ideas are organically included in the historically established national, regional and local cultures, and types of socio-political consciousness. This position correlates with findings made by Alford et al. (2005, p. 164): political ideology is very likely to be inherited in $50 \%$ or more cases. This conclusion confirms that young people do not enter the political world as "clean sheets", but bring with them 
quite stable hereditary tendencies to perceive the world, and especially a predisposition to liberal or conservative views.

An interesting conclusion was made by German scholars (Fischer et al. 2017, p. 180), that studying economics has promarket influence on political views: "by the time of graduation, economics students are some 6.2 percentage points more likely than they were in their initial year of study to agree with free-market policy positions. Studying humanities and natural sciences has a pro-leftist influence". However, in our survey, $42 \%$ of respondents study economics and management, and we have to mention that left-political views have prevailed among Moscow students despite the field of study.

The most sensitive question in political value orientations is the level of patriotism among youth. Gorshkov and Sheregi (2019, p. 108) wrote that about 74\% of Russian youth defined themselves more or less patriotic, which is partly comparable with the share we identified among Moscow students. According to the study of the image of Russia among youth in Saint Petersburg (Budko and Lukyanova 2019), along with patriotism, students have a sense of responsibility for their future and the future of Russia. We also see the active component in the definition of patriotism by Moscow students, such as obeying the laws and protecting the country. The researchers of patriotic education from Altai State University (Omelchenko et al. 2015) wrote about the role of family as the main social institution responsible for youth values, but emphasized that mass-media and the Internet have become the most important information resources, while political parties and social organizations do not pay attention to the civic education.

The level of optimism among youth deserves special attention as the indicator of the emotional component of attitudes. According to our findings, most Moscow students believe they can realize their plans for the future. However, reviewing surveys from different parts of Russia we can see the direct dependence of optimism on the socio-economic situation in the concrete region. Low standards of living, social inequality, high youth unemployment lead to decreased trust in power institutions and faith in a better, future life. Mostly it concerns the republics of the North Caucasus and the Republic of Tuva. VCIOM (2016) conducted the survey in the North Caucasus and revealed quite low levels of optimism and career opportunities among youth in North Ossetia, Dagestan, and Ingushetia. A bit more optimistic were the estimations of future opportunities by Chechen youth. In the Republic of Tuva, the youth is not satisfied with the life conditions and about $55 \%$ of respondents planned to leave the region (Sevek et al. 2016, p. 143).

Despite the geographic and economic differences between youth in Moscow and in the West and East border regions of Russia (Simonyan 2018; Martyshenko 2018), they called almost the same things that hinder their self-realization: socio-economic conditions, difficulties of employment of young people, ineffective youth policy, and unavailability of quality education. One of the serious factors of the Russian youth policy ineffectiveness is the "two poles" approach. The state aims at supporting the talented youth, on one hand, and the most vulnerable groups (orphans, children from dysfunctional families, etc.), on the other hand. "Such an approach excludes from the policy and public discourse the 'middle' youth that needs but lacks rather participation in the life of the country than financial support" (Podyachev and Khaliy 2020, p. 274).

The important indicator of cognitive level attitudes is forming the ideas about perspective fields of employment. For more than a decade, VCIOM (2019) has offered the young people in Russia to estimate the perspective spheres of employment. In 2019, the respondents included sports and creative professions (actor, musician, writer) as the most accessible professional areas. According to the survey, it is more difficult for youth to build a career in business, public administration, and politics. However, today, in comparison with 2007, the number of Russians who believe that making a career in the political sphere is difficult or almost impossible for young people has decreased by $9 \%$. The results of the regional survey conducted by Avraamova (2018, p. 131) among working youth in the Ivanovo, Sverdlovsk, and Novosibirsk regions showed the hierarchy of ideas about the currently promising specialties: lawyers, state and municipal government, financial sector, law enforcement agencies, 
engineers, medical doctors, economists, and accountants. The lower positions of the hierarchy were occupied by trade workers, scientists, teachers, and service workers.

Our findings do not contradict Avraamova's results. Despite of geographic closeness to government institutions, the employment in politics or public administration for Moscow students is almost on the same level of preferences as for peripheral youth. However, young people in Moscow pointed out as more promising spheres new technologies, trade, and even science and teaching, than youth living in regions. Can we conclude that Moscow students are less ambitious? We do not think so. This phenomenon can be explained by much more opportunities for Moscow students in terms of working in world trade companies or recognized scientific and educational centers, which make these spheres more desirable.

Modern Russian youth is characterized by low interest in political events; 75\% (Petukhov 2012, p. 59) admitted they had no interest in politics. Gorshkov and Sheregi $(2019$, p. 113) indicated the smaller share of those who are not interested in politics- $45.5 \%$. We got more encouraging results about Moscow students, but it can be explained with the fact that almost a quarter of our respondents study political science and public administration. Nevertheless, sometimes even students quite knowledgeable in social and political issues during seminar classes and political discussions can say quite popular phrases among Russian youth: "we decide nothing", "everything is already done without us". Such low level of interest in politics among educated youth in the capital is alarming. In defense of young Russians, Gorshkov and Sheregi (2010, p. 83) argue that interest in politics comes with age, when the welfare of people and their families depends on social position.

The problem of trust in authorities is a very significant indicator of cognitive level attitudes and the important factor of society consolidation. According to the international research Edelman Trust Barometer (2018), the level of institutional trust in Russia was 36\% among the countries that participated in the project, with the world average trust in institutions $48 \%$ (to compare, the UK-39\%, Germany-41\%, the US-43\%, China-74\%). Against the background of the low level of institutional trust, the level of trust in President Vladimir Putin, based on the VCIOM (2020a, 2020b) monitoring of trust in politicians, stands out. Some foreign analytics (Greene 2019) even doubted the results of the VCIOM surveys. It is connected with two methods used by VCIOM: (1) with closed-ended question with the list of politicians; (2) with open-ended question.

The results of our findings based on closed-ended questions showed that the most trusted institution for Moscow youth is the President of the Russian Federation (63.7\%), with a gap of trust in government $(29.6 \%)$. This gap can be easily explained by the fact that a new government was formed in the beginning of 2020 and did not have time to prove itself by the end of our survey. VCIOM started to estimate the level of trust to the new Head of Government Mikhail Mishustin since mid-April (52.1\%). Our findings do not contradict the results of other scholars (Nikiforov 2018; Kaminskiy 2019) and independent centers (Levada-Center 2020). Institute of Sociology of the Russian Academy of Sciences (2018, p. 36) identified three groups of public institutions according to the trust-distrust ratio:

- institutions with a positive balance of the level of trust (the number of those who trust outnumbers those who do not trust) — the President of Russia, the Russian army, the Russian Academy of Sciences, Church, public and human rights organizations;

- institutions with an approximately equal ratio of trusting and distrusting - the Russian government, the heads of the subjects of the Russian Federation;

- institutions with a negative level of trust (the number of those who do not trust exceeds those who trust)-the Federation Council, trade unions, police, local governments, the State Duma, TV, print media, the judiciary, and political parties.

On the basis of the value, emotional, and cognitive attitudes, youth formulate their life-course and strategies for the future life, first of all employment and starting a family. As for career making aspirations, material reward is not the dominant motivation among Moscow students, almost half of them prefer moral satisfaction from work and the opportunity to do what they love. The most 
controversial results are connected with factors that affect the life and career success. As we can see, the meritocratic personal features compete with right connections and necessary acquaintances. Petukhov (2012, p. 58) pointed at the formation of a dangerous stereotype among youth that material wealth, career growth, and morality could not be compatible in modern Russia. In the beginning of 2020, we nevertheless have found out the dominant share of Moscow student who believe in the significance of personal qualities and merits and good education in career making.

Despite small differences in starting a family plans between young men and women, we found that Moscow students are family oriented, more than $60 \%$ of them plan to have two or more children. Although family and children are traditionally more interesting for young women, building a career is also becoming their important life strategy. This is due to the fact that girls believe that women have fewer career opportunities, hence they have a higher motivation for self-development. It is also an all-Russian tendency registered by other researches (Martyshenko 2018, p. 225; Gorshkov and Sheregi 2019, p. 211).

The survey results indicate a low level of interest among Moscow youth in politics. Considering that we interviewed students of humanities, who are young people quite knowledgeable in social and political issues, this low level of interest in politics among educated youth in the capital is alarming. In comparison with all-Russia and regional surveys results (Stegny 2016, p. 14; Gorshkov and Sheregi 2019, p. 113), we can conclude this is a national problem. The young people of Russia do not believe they can change anything, while adults decide everything; even those who live in the capital and may soon start their career in political parties, public organization, or public administration. According to Plutzer (2002, p. 43), the "habit" of voting is acquired in early adulthood, so a low level of voting among young people may mean that they will be less inclined to participate in elections throughout their adult life. Though most scientists showed that political orientations of youth highly depend on the influence of family and elder generations (Alford et al. 2005; Cicognani et al. 2012), we believe that youth policy and the education system must pay more attention to the formation of civic culture and motivate young people to political activity.

\section{Conclusions}

Our study of socio-political attitudes of youth was conducted in the city with much more opportunities for career and self-realization, with the best socio-economic conditions, and the highest living standards in our country.

On the value level of social attitudes, Moscow students are typical representatives of the young generation of Russia, with normal life priorities to have a family, reach material well-being, and have a good health. They share the older generation's values for a better political system with a little nostalgia for the Soviet Union and express patriotic feelings. On this level, the influence of gender is clearly manifested, so girls are more focused on the family and the material base, and young men on career, fame, and power. The influence of the field of study manifested itself only in the active component of the patriotism concept; engineers defined it as the defense of the homeland with arms in hand, while the humanities students defined it as national pride and compliance with laws.

There are more similarities than differences in social attitudes of Russian youth on the emotional level, except for the low youth optimism in several regions with economic difficulties. Among Moscow students we identified a large proportion of optimists in regards to the implementation of their life plans; a fairly significant part of the respondents stated that their well-being depends only on themselves. Most of Moscow students prefer to solve emerging problems in case of violation of their rights within the legal framework and are not inclined to protest.

On a cognitive level, young people are aware of their capabilities and assess their place in the public sphere. The estimation of perspective fields of employment did not show dependence on gender or field of study, only on a socio-economic context, so Moscow students noted technologies, trade, public administration, and law. They demonstrated moderate interest in socio-political events (men 
more than women), and low trust in the main public institutions (girls expressed more trust in public administration, and young men in representatives of business).

Based on fundamental values, the youth build their life strategies and aspirations. Despite of the field of their study, students in Moscow can be described as quite energetic young citizens, equally family and career oriented. They are characterized by weak political activity. Discussing the findings with all-Russia and regional surveys authors, we conclude that low political activity of young people is a national problem.

The opinion of young people about what hinders their life plans suggests several priority measures. It is necessary to increase the effectiveness of the Moscow youth policy, especially in expanding the employment opportunities for university graduates, to spread more information about existing youth programs, and expand access to quality education. The political system should be open to the problems and interests of young citizens, and their participation depends on whether they consider themselves to be an important subject of the social and political process.

\section{Limitations}

The authors partly used the instruments of all-Russia and reginal youth studies previously conducted by different scholars and scientific centers, and discussed their main findings with results obtained by other scientists in order to clarify the social context and the Russian national specifics. However, exhaustive comparison was impossible as all that research was conducted in different years (2010-2019) and based on different samples.

Author Contributions: Conceptualization, T.L. and O.V.; Investigation, T.L., O.V. and G.M.; Methodology, T.L.; Writing-original draft, T.L.; Writing-review \& editing, O.V. and G.M. All authors have read and agreed to the published version of the manuscript.

Funding: This research received no external funding.

Conflicts of Interest: The authors declare no conflict of interest.

\section{References}

Alford, John R., Carolyn L. Funk, and John R. Hibbing. 2005. Are political orientations genetically transmitted? American Political Science Review 99: 153-67. [CrossRef]

Allport, Gordon W. 1935. Attitudes. In Handbook of Social Psychology. Edited by Carl Murchison. Worcester: Clark University Press, pp. 798-884.

Avraamova, Elena M. 2018. Russian Youth Employment Trends in Regions. Sociological Studies 9: 130-34. (In Russian) [CrossRef]

Bedolla, Lisa García. 2010. Good Ideas Are Not Enough: Considering the Politics Underlying Students' Postsecondary Transitions. Journal of Education for Students Placed at Risk 15: 9-26. [CrossRef]

Budko, Diana A., and Galina V. Lukyanova. 2019. Image of an ideal Russia in the consciousness of student youth. RUDN Journal of Political Science 21: 184-94. (In Russian) [CrossRef]

Cawvey, Matthew, Matthew Hayes, Damarys Canache, and Jeffery J. Mondak. 2017. Personality and Political Behavior. Politics, Oxford Research Encyclopedia. Available online: http://politics.oxfordre.com/view/10.1093/ acrefore/9780190228637.001.0001/acrefore-9780190228637-e-221?rskey=yLGPES\&result=10 (accessed on 11 August 2020).

Cicognani, Elvira, Bruna Zani, Bernard Fournier, Claire Gavray, and Michel Born. 2012. Gender differences in youths' political engagement and participation. The role of parents and of adolescents' social and civic participation. Journal of Adolescence 35: 561-76. [CrossRef]

Davies, Ian, and Sylvia Hogarth. 2004. Political Literacy: Issues for Teachers and Learners. In Citizenship and Political Education Today. Edited by Jack Demaine. London: Palgrave/Macmillan, pp. 41-58.

Diligenskiy, German G. 1994. Sotsial'no-Politicheskaya Psikhologiya [Socio-Political Psychology]. Moscow: Nauka, 304p. (In Russian)

Edelman Trust Barometer. 2018. Global Report. Available online: https://www.edelman.com/sites/g/files/aatuss191/ files/2018-10/2018_Edelman_Trust_Barometer_Global_Report_FEB.pdf (accessed on 11 August 2020). 
Federal State Statistic Service. 2020. Population by Age Groups. Available online: https://gks.ru/folder/12781 (accessed on 7 July 2020). (In Russian)

Feldman, Stanley, and Christopher Johnston. 2014. Understanding the Determinants of Political Ideology: Implications of Structural Complexity. Political Psychology 35: 337-58. [CrossRef]

Fischer, Mira, Björn Kauder, Niklas Potrafke, and Heinrich W. Ursprung. 2017. Support for free-market policies and reforms: Does the field of study influence students' political attitudes? European Journal of Political Economy 48: 180-97. [CrossRef]

Galston, William A. 2001. Political Knowledge Political Engagement and Civic Education. Annual Review of Political Science 4: 217-34. [CrossRef]

Gorshkov, Mikhail K., and Franc E. Sheregi. 2010. Molodezh' Rossii: Sotsiologicheskiy Portret. [Youth of Russia: A Sociological Portrait]. Moscow: Institute of Sociology RAS, 592p, Available online: https://www.isras.ru/ publ.html?id=1822\&type=publ (accessed on 7 July 2020). (In Russian)

Gorshkov, Mikhail K., and Franc E. Sheregi. 2019. Russian Youth within the Context of Sociological Analysis. Moscow: Institute of Sociology RAS, 263p, Available online: https:/www.isras.ru/index.php?page_id=1198\&id=7555 (accessed on 7 July 2020). (In Russian)

Greene, Samuel A. 2019. Russians' trust in Putin has plummeted. But that's not the Kremlin's only problem. The Washington Post. June 4. Available online: https://www.washingtonpost.com/politics/2019/06/04/ russianss-trust-putin-has-plummeted-thats-not-kremlins-only-problem/ (accessed on 11 August 2020).

Inglehart, Ronald. 1990. Culture Shift in Advanced Industrial Societies. Princeton: Princeton University Press.

Institute of Sociology of the Russian Academy of Sciences. 2018. Russian Society after the 2018 Presidential Election: A Request for Change. Available online: https://www.isras.ru/files/File/publ/Ros_obschestvo_ posle_prezident_vyborov_2018.pdf (accessed on 11 August 2020). (In Russian)

Kaiser, Fred M., and Robert Lilly. 1975. Political attitudes among students: A small college experience. Adolescence 10: 287-94.

Kaminskiy, Vadim S. 2019. Attitude to power as an element of social well-being (case study of the Vologda oblast). Territorial Development Issues 5: 1-14. (In Russian) [CrossRef]

Simonyan, Renald Kh. 2018. Student youth of the border regions of Russia. Sociological Studies 4: 82-89. (In Russian) [CrossRef]

Kohlberg, Lawrence. 1984. The Psychology of Moral Development: The Nature and Validity of Moral Stages. San Francisco: Harper \& Row, 729p.

Levada-Center. 2020. Putin's Approval Rating. Available online: https://www.levada.ru/en/ratings/ (accessed on 11 August 2020).

Lipset, Seymour Martin. 1983. Political Man, 2nd ed. Garden City: Doubleday.

Litvinova, Tatiana N. 2018. Political orientations of Moscow student youth. Politics and Society 9: 63-75. (In Russian) [CrossRef]

Lovat, Terence, Ron Toomey, and Neville Clement. 2010. International Research Handbook on Values Education and Student Wellbeing. Edited by Ron Toomey and Neville Clement. Berlin: Springer Science \& Business Media, 1015p.

Martyshenko, Natalya S. 2018. The role of the students valuable indicators in the formation of the regional human capital. Azimuth of Scientific Research: Economics and Administration 7: 223-28. (In Russian)

Mishler, William, and Richard Rose. 2007. Generation, age, and time: The dynamics of political learning during Russia's transformation. American Journal of Political Science 51: 822-34. [CrossRef]

Mosstat. 2020. Educational Institutions of Higher Professional Education in Moscow. Available online: https://mosstat.gks.ru/folder/64643 (accessed on 7 July 2020). (In Russian)

Nikiforov, Yaroslav A. 2018. Trust to the Authorities in the Regional Context: Sociological Measurement. Izvestiya Saratov University (Novaya Seriya) Seriya Sociology Politology 18: 120-23. (In Russian) [CrossRef]

Omelchenko, Daria, Svetlana Maximova, Galina Avdeeva, Natalia Goncharova, Oksana Noyanzina, and Olga Surtaeva. 2015. Patriotic education and civic culture of youth in Russia: sociological perspective. Procedia Social and Behavioral Sciences 190: 364-71. [CrossRef]

Order of the Government of the Russian Federation. 2014. On Approval of the Fundamentals of State Youth Policy until 2025. November 29, N 2403-p. Available online: http://government.ru/docs/15965/ (accessed on 7 July 2020). (In Russian) 
Petukhov, Vladimir V. 2012. The generation of the «2000s»: ideological orientations and political participation. Polis Political Studies 4: 56-62. (In Russian)

Piaget, Jean. 1972. Intellectual evolution from adolescence to adulthood. Human Development 15: 1-12. [CrossRef]

Plutzer, Eric. 2002. Becoming a Habitual Voter: Inertia, Resources, and Growth in Young Adulthood. American Political Science Review 96: 41-56. [CrossRef]

Podyachev, Kirill V., and Irina A. Khaliy. 2020. The state youth policy in contemporary Russia: concept and realities. RUDN Journal of Sociology 20: 263-76. (In Russian) [CrossRef]

Rokeach, Milton. 1968. The nature of attitudes. In Beliefs, Attitudes and Values. Edited by Milton Rokeach. San-Francisco: Josey-Bass, pp. 109-32.

Rokeach, Milton. 1973. The Nature of Human Values. New York: The Free Press.

Sazonova, Anna L. 2014. Educational and professional potential of Moscow youth and problems of its implementation (based on the results of a sociological study). MIR (Modernization. Innovation. Research) 5: 86-91. (In Russian)

Sevek, Vyacheslav K., Shonchalay Ch. Soyan, and Ruslana M. Sevek. 2016. Social well-being of youth in the Republic of Tuva. Sociological Studies 9: 141-44. (In Russian)

Shevchenko, Olga Mikhailovna, and Victoria Olegovna Vagina. 2017. Civil Patriotism as an Idea of Youth Consolidation in the South of Russia: The Specifics and Difficulties of Formation. Humanities of the South of Russia 6: 300-9. (In Russian) [CrossRef]

Stegny, Vasiliy N. 2016. Political orientations of students: types, factors, features. PNRPU Sociology and Economics Bulletin 2: 8-17. (In Russian)

VCIOM. 2016. Youth of the North Caucasus: Traditions and Modernity. Available online: https://wciom.ru/index. php?id=236\&uid=356 (accessed on 7 July 2020). (In Russian)

VCIOM. 2019. Career of Russian Youth: Prospects and Difficulties. Available online: https://wciom.ru/index.php? $\mathrm{id}=236 \&$ uid $=9905$ (accessed on 7 July 2020). (In Russian)

VCIOM. 2020a. Trust in Politicians (1). Available online: https:/wciom.ru/news/ratings/doverie_politikam_1/ (accessed on 11 August 2020). (In Russian)

VCIOM. 2020b. Trust in Politicians (2). Available online: https://wciom.ru/news/ratings/doverie_politikam/ (accessed on 11 August 2020). (In Russian)

Verba, Sidney, and Gabriel Almond. 1963. The Civic Culture: Political Attitudes and Democracy in Five Nations. Princeton: Princeton University Press, 574p.

Welzel, Christian, and Ronald Inglehart. 2010. Agency, Values, and Well-Being: A Human Development Model. Social Indicators Research 97: 43-63. [CrossRef] [PubMed] 